\title{
Are the Malaysian Adolescents' Behavior At-Stake?
}

\author{
Siti Rafiah Abd Hamid, Ph.D \\ Kulliyyah of Education, International Islamic University Malaysia, Assistant Professor \\ srafiah60@iium.edu.my \\ Khamsiah Ismail, Ph.D \\ Kulliyyah of Education, International Islamic University Malaysia, Assistant Professor \\ ikhamsiah@iium.edu.my \\ Supiah Saad, Ph.D \\ Kulliyyah of Education, International Islamic University Malaysia, Assistant Professor \\ susaad@iium.edu.my \\ Muhd Burhan Ibrahim, Ph.D \\ Kulliyyah of Education, International Islamic University Malaysia, Assistant Professor \\ mburhan@iium.edu.my \\ Norwati Mansur, Ph.D \\ Kulliyyah of Education, International Islamic University Malaysia, Assistant Professor \\ nurmansur@iium.edu.my
}

Doi:10.5901/mjss.2015.v6n2s5p328

\section{Abstract}

This study explored attributes of at-risk behaviors amongst Malaysian adolescents in secondary school and factors underpinning these behaviors. Clustered random sampling procedure was administered and approximately 738 respondents' questionnaires were finally considered for the final analyses of the data collected. A survey form which comprised demographic variables, types of at-risk behaviors and factors affecting them was pilot-tested and administered. Descriptive statistics (namely mean scores and standard deviations) was employed to describe the demographic variables related to Malaysian adolescents and types of at-risk behaviors prevalent among Malaysian adolescents. Inferential statistics (Anova and t-tests) were administered for comparing gender, age, and location - urban versus rural, family SES differences as regard to the type of atrisk behaviors prevalent. Findings based on the descriptive statistic and inferential statistics indicated that incidences of at-risk behaviors such as substance abuse, alcohol consumptions, suicide ideations and attempts, pre-marital sex, teen pregnancy and abortion, runaways were minimal and not alarming. Findings from this study shed light on the importance of developing intervention strategies which involved all quarters namely; parents, school, society and positive portrayal of adolescents' image and icons via media in our attempt to improve the life quality of adolescents.

Keywords: Adolescence, at-risk behaviours, smoking habits and substance abuse, suicide ideations and attempts premarital sex orientation, abortion, runaways.

\section{Introduction}

Every child develops at different rate and phase in his or her life. Child's development is very much influenced by the elements of "nature versus nurture" i.e. developmental aspects which are very much influenced by his/her genetic makeup and as well as the environment he/she grew in. Findings from research have also indicated that children from the baby boomer's period are different from the generation $X$ and generation $Y$ children. (Jackson, 2012; McKay, 1997).

Children from the baby boomer's period were said to be highly disciplined and displayed good working ethics and motivation to work. Children from generation $\mathrm{X}$ were said to be highlydependent and children from generation $\mathrm{Y}$ were known to be playful and least accountable for their own doings. Based on these observations, it is possible to deduce that the "nature versus nurture" debate truly has strong influence in shaping contemporary children's behavior, attitude, perception and mentality.

Parenting style is also a notable aspect of "nurture" which very much shapes the children to become either responsible or irresponsible adults in their later years. Their early childhood experiences may shape them to become 
responsible or irresponsible adults. Brought up via "permissive" or "lassaire faire" upbringing is known to destroy children's behavior. Authoritarian on the other hand is known to hamper normal children's development.

Many of the 20th through the 21st centuries children were left to thrive on their own and labelled as "latch-key kids". Unready for many things but involuntarily forced to pull their way through adolescence and adulthood.From the psychological point of view, adolescence is known as the period of "storm and stress". This is the stage where adolescents experience rapid physical development and hormonogenal changes.

According to Santrock (2011), adolescents experience pressure from both external and internal sources. They also crave for recognition, love and attention from significant others. Their inability to cope with problems and to delay their gratifications would result in hasty and bad decision-makings. When confronted with severe problems, they become suicidal, turn to substance abuse, involve in gangsterism, addicted to pornography, engage in illegal racing (motorcycle/car), human trafficking and vandalism.

All these may lead children to commit immoral offences such as sodomy or unconsented sexual intercourse (rape, incest or molestation). For example, a boy was found a leader of an illegal group in his school and the girl was found sexually active with adults outside school hours. There were phase two students from a primary school in the Klang Valley. This case study was conducted for IIUM action research subject for counseling students. This scenario was captured unintentionally by the researchers during the group dynamic.

Such an alarming rate of social misconduct creates awareness and concern among educators, education administrators and policy-makers. In line with the country's ten years Education Blueprint strategies, the Daily School Management Division (Ministry of Education) collaborated with IIUM researchers and undertaken a study related to at-risk behavior among Malaysian secondary school students.

The aim of the study is to identify types of at-risk behaviors among secondary school adolescents and to examine attributing factors of this social misconduct

A survey on the adolescents' behavior issue were examined for the purpose of this study. Clustered sampling procedure will be applied in five zones throughout Malaysia. Data were examined via descriptives and inferential statistics.

\section{The Purpose of the Current Study}

In the context of this study, the alarming rate of social misconduct (ie. suicide ideation and teen rape cases) has raised awareness and concern among Malaysian parents, educators, education administrators and policy-makers and nongovernmental organizations (NGOs). In line with the country's ten years Education blueprint strategies (year 2013-2025) and the national philosophy of education, the Ministry of Education has stepped in and aspired to develop the students holistically. The main objective of this paper to explore the current truth related to adolescents' at-risk behaviors in secondary schools throughout the country and to highlight these findings to the appropriate parties concerned for further action.

\section{Problem Statement and Justifications}

The rise of at-risk behaviours namely substance abuse, suicide ideation and premarital sex engagement among the Malaysian youths is a new pattern of life in Malaysia which requires new body of information. Minimal empirical research and information related to the above matter in the Malaysian context need to be addressed seriously so to as to minimise or at least to bring the youth social problems to a standstill. Our inability to address and ease the problem will result in massive loss of potential human capital for the future. Empirical data related to understanding adolescent's developmental crises in Malaysia is still minimal, thus this study aimed at addressing this gap and intended to examine the Malaysian adolescents' developmental needs and related emerging issues.

The objectives of this study are:

1. To identify the highly at-risk behaviors of Malaysian lower secondary school students. (items: 41 - 105)

2. To investigate the contributing factors towards the highly at-risk behaviors among Malaysian Lower secondary school students.

3. To examine significant differences in terms of at-risk behaviors as regard to the following demographic variables:
a. Gender
b. Age
c. Family SES 
d. Student's background (urban versus rural)

e. Parents' marital Statuses

\section{Research Questions}

1. What are the at-risk behavior found among Malaysian lower secondary school pupils?

2. What are the contributing factors towards the rise of highly at-risk behaviors among Malaysian lower secondary school pupils.

3. Are there significant differences with respect to at-risk factors as regard to the following"
a. Gender
b. Age
c. Family SES
d. Student's background (urban versus rural)
e. Parents' marital statuses

\section{Literature Review}

There was an alarming increase of crime rate among adolescents in Malaysia (Ting, 2011). These socially unacceptable behaviors are becoming a concern of every sector at governmental and individual level for they disrupt the society in many ways (Mey, 2010; Kassim, 2006). In Malaysia, more efforts have been exerted to curb the situation, however, fewer studies have been conducted to explore highly at-risk misconducts or behaviors among adolescents so that counselors, teachers or psychologists alike may address them proactively and appropriately (Mey, 2010).

Numerous studies have identified that, successful counseling programme is needed in preventing at-risk behaviors among the youth in order to guide them to be more productive and functional members of the society (Chaih \& Baharudin, 2012; Hishinuma, Johnson, Kim, Nishimura, Makini, Andrade, Yates, Goebert, Mark, Mayeda, \& Revilla, 2005). Youths' inability to abandon their negative behaviors may impede the learning process and results in school dropout eventually (Morton, Crump, Haynie \& Saylor, 1999; Mey, 2010; Ting, 2011).

Statistics has shown that, from the year 2000 through 2007, numerous light and heavy offenses have been committed by students in Malaysian schools (Malaysia Department of Social Welfare, 2006; Malaysia Ministry of Education, 2008) namely: drug abuse (Malaysia Anti-Drug Association, 2005), pornography, impoliteness, destructive behavior, inappropriate dressing, truancy (Mey, 2010), rude and aggressiveness, crime, hooliganism, indecent behaviors, and vandalism (Malaysia Department of Statistics, 2007) to name a few.

A study on Malaysian adolescence and violence in one of the Malaysian states indicated that they were mostly involved in physical fights, injured in fights and carried weapons (Lee, Chen, Lee, \& Kaur, 2007).

Moral decadence and delinquency were not only limited or confined to Malaysian youths but are globally prevalent. Theoretically, authors have demonstrated that, the drastic surge of problem behaviors namely; substance use, school misconduct and delinquency during adolescence are the national concern in many societies (Morton, Crump, Haynie \& Saylor, 1999; Dryfoos, 1990; Feldman and Elliot, 1990; USDHHS, 1991; Takanashi, 1993).

Empirically, cross-cultural studies conducted in U.S which compared U.S, Australian and Asian youths regarding behavior disorders revealed that, youth in the United States and Australia engaged in more misconduct than those in Asia (Greenberger, Chen, Beam, Wang, \& Dong, 2000; Jessor, Turbin, Costa, Dong, Zhang \& Wang, 2003; Weisz, Chaiyasit, Weiss, Eastman \& Jackson, 1995). A study carried out among Hong Kong youth found that those who were more westernized involved in greater misconduct (Cheung-Blunden \& Juang, 2008) as opposed to those who embraced traditional lifestyle.

Anti-social behaviors in tender age almost transpire due to the fact that adolescents are searching for their identity and autonomy. This requires them to struggle with the transitional stage from childhood to adulthood (Mey, 2010).

From the developmental psychology perspectives, adolescence is seen as a period of "storm and stress". It involves biological, cognitive, socio-emotional (Ting, 2011), and psychological transformation (Ozer, Macdonald \& Irwin, 2002; Arredondo, 2003; Reinherz, Paradis, Giaconia, Stashwick \& Fitzmaurice, 2003; White, 2004; Papathanasiou \& Lahana, 2007). These changes vary widely in timing and tempo (Brooks-Gunn, Petersen, Eichorn, 1985; Feldman and Elliott, 1990).

Adolescence is a stage where adolescents experience rapid physical development and hormonogenal changes. According to Santrock (2011) adolescents at this stage, experience pressure from both external and internal sources. Their inability to delay their gratifications and to cope with pressures would result in unexpected and premature hasty 
problem solving and abrupt decision-making.

Examples of which are; suicide ideation or attempts, motivated to be sexually active, engage in substance abuse, opts truancy or commit heavy sexual offences namely; sodomy or unconsented sexual intercourse (rape, incest or molestation) or extortation.

Since, adolescent's highly at-risk behavior has been identified as being too costly to the nation, an impediment to education, society and the country as a whole, it would be worthwhile to identify and understand the factors that underlie their misconduct and to identify effective interventions which have been found instrumental by researchers in recent years. This vital information will be instrumental to all stakeholders namely; the Malaysian Ministry of Education, policy makers, school counselors and educators alike.

\title{
6. Adolescents and Highly At-Risk Behaviors
}

Review of existing literature suggested that multiple factors predict highly at risk behaviors of adolescents. Kassim, (2006) stated that:

\begin{abstract}
"The increase in criminal misconduct among adolescents is influenced by several factors particularly involving those directly involved with adolescent development such as parents, the school, the family, social institutions, the community and the government" (p.2).
\end{abstract}

\section{Youth Socialization and Engagement}

Several studies revealed that, Asian Americans' involvement in problem behavior (Choi \& Lahey, 2006; Kim \& Goto, 2000; Zhou \& Bankston, 1998) is an indication of unsuccessful socialization (Feldman, Rosenthal, Mont-Reynaud, Leung, \& Lau, 1991) which predicts later problems as adults (McCord, 1990).

\section{Parenting Styles and Family Conflicts}

Empirical studies have shown that parental monitoring buffered problem behavior (Barnes, Hoffman, Welte, Farrell, \& Dintcheff, 2006), while poor parenting practices (Blumstein, Farrington, \& Moitra, 1985; Hoge, Andrews \& Leschied, 1994; Klein, Forehand, Armistead, Long, 1997) were found to be related to adolescent misconduct. In addition, research shows that, family mismanagement was reported to be highly correlated with male misconduct during adolescence and a predictive of criminality that continued into adulthood (Loeber \& Dishion, 1983).

Studies based on Bandura's theory indicated that conduct disorder/immoral behavior is hereditary. On one hand, it is also possible that adolescents will emulate/imitate these behaviors as a result of experiences with their environment. For instance, a young boy who always sees his father battering his mother would be more than likely to become an abusive parent and husband in the future (Lai, 2011; Siegel, 1992).

Replicated or experimental studies found that adolescents with conduct disorder came from families with significant lower levels of interconnection (Haddad, Barocas, \& Hollenbeck, 1991) and families with conduct disorder adolescents have higher levels of aggression (Dadds, Sanders, Morrison, \& Regbetz, 1992; Fendrich, Weissman, \& Warmer, 1991; Lai, 2011).

According to David and Murphy (2004), the more children are exposed to their parents' marital conflicts, incompatible personality, relationship dissatisfaction and even violence the most they would develop negative personality traits such as aggressiveness, impulsivity, negative attitude towards school or academic achievement, experience peer rejection and exposure to delinquent behaviors.

\section{Peer Influence}

Findings from studies conducted among U.S., Korean and Chinese youths showed that bad companionship results in more adolescent misbehavior (Greenberger, Chen, Beam, Wang \& Dong, 2000). It was also found that close friend's misconduct was found to be positively associated with adolescents' serious trouble with the law and aggressive symptoms (Hishinuma, Johnson, Kim, Nishimura, Makini, Andrade, Yates, Goebert, Mark, Mayeda, \& Revilla, 2005). Peer group influence has also been found as a predictor of social misconduct among adolescents and juveniles (Kassim, 2006). 


\section{Spiritualism and Morality}

Fewer studies have examined the importance of spirituality or in depth understanding of religious knowledge which may impede juvenile delinquency (Kassim, 2006). In some studies, full involvement in religious activities buffers the chance to engage in violence or misbehavior (Herrenkohl, Tajima, Whitney and Huang, 2005).

\section{Other Predictors of Misconduct Identified}

Poverty and mental disorder are said to have caused social problems among juveniles (Kassim, 2006). Delinquency may be attributed by; conflict with the authority, cognitive distortions, personality disorders, and most common than not juvenile's socioeconomic status (Santrock, 2008).

Other common factors namely; lack of social skills, low social competency, low academic achievement, negative attitudes toward school and lack of parental guidance have commonly been identified as highly at-risk factors for causing problem behavior among juveniles (Hawkins and Weis, 1985; Dryfoos, 1990; Steinberg, 1990; Schinke, Botvin, Orlandi, 1991).

\section{Methodology}

This study will employ qualitative and quantitative research methods; using survey, focus group interview and observation in collecting the data. Result from the survey will be discussed in series of focus group workshops for improvement. While for the open-ended interview data gained from counselors and clients will be triagulated. Sample will be chosen using multi stages clustered sampling procedure in all states throughout Malaysia. The sample will cover rural and urban area, minority and at risk students (remote area, orang asli and students with special needs).

\section{Sampling Procedure}

The targeted population the study intends to generalize its findings is Lower Secondary School students in Malaysia. This population will include all Form Two students in Lower Secondary Schools in the northern, central, southern, and eastern zones of Peninsular Malaysia and also the Sabah and Sarawak zones.

The sample representing the Form Two student's population will be selected using the random sampling procedure. Random sampling procedure has been chosen to increase generalizability through a good cross-section of the population which is truly representative of the population. Representative sampling enables the researcher to generalize and make claims of knowledge about the population. According to Gay and Airasian (2006) samples should be as large as possible; in general, the larger the sample, the more representative it is likely to be, and the more generaliszable the results of the study are likely to be.

The sampling in this study will be collected via the multi-staged clusted sampling procedure at the institutional level and followed by convenient sampling procedures during visits to the institutions to meet the respondents. In this study the targeted Form Two students were selected based on the randomization of parliamentary constituencies of each state and later narrow down to northern, middle, southern, east coast states and East Malaysia zones. From each constituency, three rural and three urban schools were selected.

The current total enrollment of secondary school students from West and East Malaysia is 2,299,669 (Ministry of Education Malaysia, 2013). Based on Krejcie and Morgan (1970) if the total population is 1,000,000, hence the sample size recommended is 384 respondents. However due to students' diversity in this country, problems related to form's completion and the return rate are critical, hence this study has identified randomly 60 schools throughout Malaysia, and has selected 1,500 secondary school students to participate in this study. Kindly refer to the schools listed in Appendix E.

Selection in each zone is based on several important features; that is urban and rural schools; types of schools (A, $B$ and $C$ ), students' population as representativeness is given a priori.

As for the second level of data collection, open-ended interview sessions (via prepared interview protocols) with selective school counselors will be conducted. In the multi-staged clustered sampling procedure, schools in all states of Malaysia will be considered as the population to be studied. located in the northern, middle, southern, eastern zones as well as schools in east Malaysia will be taken into consideration. The sample will be representative in terms of school location (both rural and urban schools), minority and at risk students (remote area, orang asli and students with special needs). 


\section{Pilot Study}

A pilot study was conducted in November 2012 and a secondary school in the Klang Valley was identififed. Approximately 81 participants participated in the pilot study. The items in the questionnaire uses differing likert scales for the different constructs measured by this study. The pilot study yields astounding reliability estimates except for suicide ideations and attempts. Most of the major constructs used Likert scale of 1 (strongly disagree) through 5 (strongly agree). Table 1 tabulates the individual realiability estimates of each construct measured. The aplha values ranged from as a low of 0.52 through a high of 0.98 .

Table 1: Pilot study Internal Reliability Estimates of Constructs

\begin{tabular}{lcc}
\hline \multicolumn{1}{c}{ Highly at-risk behaviors constructs } & Items & Internal Reliability Estimates \\
\hline Sunstance Abuse (Tobacco, alcohol, drugs and related reasons) & 41 through 62 & .801 \\
Suicide ideation / suicide attempts & 63 through 71 & .818 \\
Runaways and related reasons & 77 through 90 & .875 \\
Sex, pregnancy, abortion and related reasons & 91 through 102 & .984 \\
\hline
\end{tabular}

\section{Instrumentation}

An instrument has been developed which is known as the Highly At-Risk Behaviors Questionnaire (a questionnaire to gauge adolescents highly at-risk behaviors) - HARBQ. Approximately 1,500 questionnaires were posted to 60 schools (with the urban and rural features selected randomly) throughout Malaysia. 800 questionnaires were returned through snail mail but only 738 questionnaires were finally considered for analysis due to the completion of the information found in the questionnaires.

The original questionnaire had 94 items and was administered on secondary public schools located in the urban and rural areas of Peninsula Malaysia, Sabah and Sarawak. These questionnaires were sent through snail mail (Poslaju service) to these schools together with an enclosed Poslaju envelope. However for the purpose of this paper only the demographic items and at-risk behaviors items (41-94) were analyzed and tabulated in the tables and figures.

\section{Data Collection}

In the context of this study, stratified multistage sampling procedure has been identified. For instance if we were to do a national survey of adolescent's highly at-risk behaviors, stratified sampling would first be used to select the urban, semi urban and rural geographical school locations for study.

In this study, the states in Malaysia will be classified randomly as the following: Northern states (Perlis, Kedah and Pualau Pinang); Central states (Perak, Selangor and Wilayah Perrsekutuan Kuala Lumpur); Southern states (Negeri Sembilan, Melaka and Johor); Eastern states (Kelantan, Terengganu and Pahang) and East Malaysian states (Sabah and Sarawak). Data will be collected from the aforementioned zones. The total population came from the number of secondary school students enrolled early in 2013. In the second stage, the secondary schools were assigned according to zones In the third stage, 60 schools were randomly drawn from these zones and 1,500 students were identified. Finally 25 boys and 25 girls were selected from each school to participate in this study.

Table 2: Data Analysis

\begin{tabular}{|c|c|c|}
\hline \multicolumn{2}{|c|}{ No. Research Question } & Statistical Analysis \\
\hline 1 & What are the at-risk behaviors found among Malaysian lower secondary school pupils? & $\begin{array}{l}\text { Descriptives (Means, Standard Deviations), } \\
\text { Percentages. }\end{array}$ \\
\hline 2 & $\begin{array}{l}\text { What are the contributing factors towards the rise of highly at-risk behaviors among Malaysian } \\
\text { lower secondary school pupils. }\end{array}$ & Linear Multiple Regression Analysis (MRA) \\
\hline 3 & $\begin{array}{ll}\text { Are } & \text { there significant differences in terms of at-risk behaviors as regard to: } \\
\text { a. } & \text { Gender } \\
\text { b. } & \text { Age } \\
\text { c. } & \text { Students's Location (urban versus rural) } \\
\text { d. } & \text { Family SES } \\
\text { e. } & \text { Family types }\end{array}$ & Anova \& $t$-tests \\
\hline
\end{tabular}




\section{Justification}

It is fervently hoped that findings from this study may shade some lights on the current situation of highly at-risk behaviors among secondary school students in this country. The findings will be instrumental to both the Ministry of Education Malaysia and as well as the School Counseling Unit and help identify their strengths and weaknesses. The strengths of the counseling units may be recorded and emulated by other counselors and they may further react or respond to the grey areas identified by this study.

\section{Findings}

The number of schools met the targeted $95 \%$ of the confidence interval. Several respondent's demographic variables were identified namely; age, gender, mother tongue, religions, home address, type of home, parents' marital statuses, siblings, stay with siblings, stay with grandparents, marital status, frequency of communicating with mom, frequency of communicating with dad, raised by both parents, closer to either parent.

The response rate is equivalent to $74.7 \%$. According to Diem (2003) $50-60 \%$ of response rate is classified as an acceptable return rate for any survey research. Babbie (1989) mentioned that if the return rate is $50 \%$ it is then considered adequate, $60 \%$ of response rate is considered good and the response rate of $70 \%$ is considered as very good. Thus, this allows the researchers to proceed with the data analysis.

\section{Demographic Variables}

The following are the demographic characteristics of the respondents of the study undertaken. Table 3 tabulates the age range of the respondents who completed the entire questionnaire. Comparatively the respondent's age ranged from as young as 13 through 17 years old. Apparently majority of the respondents were 15 (230) years old, 14 years old (193), 17 years old (142), 16 years old (91) and the least was 13 years old (82).

Table 3: Age Range

\begin{tabular}{c|c|c}
\hline Demographic Variables & Frequency & Percent \\
\hline Age Range & 82 & 11.1 \\
13 & 193 & 26.2 \\
14 & 230 & 31.2 \\
15 & 91 & 12.3 \\
16 & 142 & 19.2 \\
17 & 738 & 100 \\
Total & - & - \\
Missing & 738 & 100 \\
Grand Total & & \\
\hline
\end{tabular}

Table 4 tabulates the gender break down of the respondents' gender whose questionnaires were finally analysed. The difference between male and female respondents were 102.

Table 4: Respondent's Gender

\begin{tabular}{ccc}
\hline Respondent's Gender & Frequency & Percent \\
\hline Male & 304 & 41.2 \\
Female & 406 & 55.0 \\
Missing (9) & 28 & 3.8 \\
G. Total & 738 & 100 \\
\hline
\end{tabular}

Comparatively, there were more females 406 (55.0\%) as opposed to males 304 (41.2\%). These breakdown of gender is basically based on the number completed items found in the questionnaires.

Table 5 depicts the respondents' mother tongue. Apparently, the respondents mostly spoke the national language, Bahasa Malaysia 523 (70.9), followed by the Chinese dialect 131 (17.8\%), other ethnic languages 24 (3.1), and Tamil speakers $22(3.0)$. 
Table 5: Respondent's Mother Tongue

\begin{tabular}{ccc}
\hline Mother Tongue & Frequency & Percent \\
\hline Malay Language & 523 & 70.9 \\
English Language & 13 & 1.8 \\
Chinese Language & 131 & 17.8 \\
Tamil Language & 22 & 3.0 \\
Others & 24 & 3.1 \\
Missing (9) & 25 & 3.4 \\
Total & 738 & 100 \\
\hline
\end{tabular}

Table 6 depicts the respondents' belief system. Majority of the respondents were Muslims 510 (69.1), followed by Buddhist 138 (18.7), Hindu 19 (2.6), free thinkers 9 (1.2), and others 57 (7.7).

Table 6: Respondent's Religion

\begin{tabular}{ccc}
\hline Religion & Frequency & Percent \\
\hline Islam & 510 & 69.1 \\
Buddhist & 138 & 18.7 \\
Hindu & 19 & 2.6 \\
Free thinker & 9 & 1.2 \\
Others & 57 & 7.7 \\
Missing (9) & 5 & 0.7 \\
Total & 738 & 100.0 \\
\hline
\end{tabular}

Accordingly, Table 7 tabulates the respondents' parental marital statuses. Comparatively 648 (87.8) of the respondents' parents were still married, 52 (7.0) of the respondents' parents were divorced, $10(1.4)$ of the respondents' parents were separated, and finally 12 (1.6) of the respondents' parents cohabitated.

Table 7: Respondent's Parental Marital Status

\begin{tabular}{ccc}
\hline Parental Status & Frequency & Percent \\
\hline Married & 648 & 87.8 \\
Divorced & 52 & 7.0 \\
Separated & 10 & 1.4 \\
Cohabitate & 12 & 1.6 \\
Missing (9) & 16 & 2.2 \\
Total & 738 & 100 \\
\hline
\end{tabular}

\section{Findings}

This section addressed the research questions formulated for this paper and the results were discussed and tabulated in several tables which were as follow:

1. What are the at-risk behaviors identified among the Malaysian lower secondary school students?

Descriptive statistics namely frequency counts and percentages were employed to address this questions. Tables 8, 9, 10 respectively displayed information on at-risk behaviors related to smoking patterns; alcohol and substance abuse; speeding, suicide ideation and attempt, eating disorder; and premarital sex orientation as perceived by respondents. Respondents' rating ranged from "Strongly Disagree" (SD) - "1", "Disagree" - 2, "Agree" - 3, and the highest point "Strongly Agree" (SA) is "5" respectively. Negative statement was recoded for the ease of analysing. 
Table 8: Smoking Patterns

\begin{tabular}{|c|c|c|c|c|c|c|}
\hline \multirow[t]{2}{*}{ Statement } & SD & $\bar{D}$ & $\bar{A}$ & SA & \multirow[t]{2}{*}{ Mean $(\bar{X})$} & \multirow[t]{2}{*}{ "SD } \\
\hline & $\begin{array}{c}N \\
(\%)\end{array}$ & $\begin{array}{c}n \\
(\%)\end{array}$ & $\begin{array}{c}N \\
(\%)\end{array}$ & $\begin{array}{c}n \\
(\%)\end{array}$ & & \\
\hline I have smoked before & $\begin{array}{c}624 \\
(54.5)\end{array}$ & $\begin{array}{c}51 \\
(6.9)\end{array}$ & $\begin{array}{c}44 \\
(6.0)\end{array}$ & $\begin{array}{c}19 \\
(2.6)\end{array}$ & 1.55 & 1.58 \\
\hline I started smoking at the age of less than 13 years old with one or two puffs only & $\begin{array}{c}644 \\
(87.2)\end{array}$ & $\begin{array}{c}51 \\
(6.9)\end{array}$ & $\begin{array}{c}31 \\
(4.2)\end{array}$ & $\begin{array}{c}12 \\
(1.6)\end{array}$ & 2.52 & 2.94 \\
\hline I smoked more than 20 sticks of cigarette within the last 30 days. & $\begin{array}{c}653 \\
(88.5)\end{array}$ & $\begin{array}{c}23 \\
(3.1)\end{array}$ & $\begin{array}{c}45 \\
(6.1)\end{array}$ & $\begin{array}{c}17 \\
(2.3)\end{array}$ & 2.50 & 2.91 \\
\hline I smoked cigarette everyday & $\begin{array}{c}722 \\
(97.8)\end{array}$ & $\begin{array}{c}10 \\
(1.4)\end{array}$ & $\begin{array}{c}5 \\
(.70)\end{array}$ & $\begin{array}{c}1 \\
(.10)\end{array}$ & 4.34 & 3.92 \\
\hline I have no intention to quit smoking & $\begin{array}{c}679 \\
(92.0)\end{array}$ & $\begin{array}{c}20 \\
(2.7)\end{array}$ & $\begin{array}{c}20 \\
(2.7)\end{array}$ & $\begin{array}{c}18 \\
(2.4)\end{array}$ & 2.62 & 3.08 \\
\hline I did buy cigarette within the last 30 days & $\begin{array}{c}709 \\
(96.1)\end{array}$ & $\begin{array}{c}9 \\
(1.2)\end{array}$ & $\begin{array}{c}6 \\
(.8)\end{array}$ & $\begin{array}{c}14 \\
(1.9)\end{array}$ & 2.55 & 3.09 \\
\hline
\end{tabular}

$n=738$

As regard to smoking habits among students, majority of the students surveyed indicated "SD" and "Disagree" on almost all items related to it. However, a small number of students; 63(8.6) indicated "Agree" and "Strongly Agree" on the item "I have smoked beforehand" compared to 693 (61.4). Comparatively 732(99.2) of the students indicated they "Never" and "Seldom" smoked cigarette every day. With regard to item "I have bought cigarette for the last 30 days", about 718 (97.3) respondents indicated "strongly disagree" and "disagree". Approximately 699 (3.62) students surveyed indicated their intention to stop smoking despite the fact that the item is negatively worded.

Table 9: Alcohol and Substance Abused

\begin{tabular}{l|c|c|c|c|c|c}
\hline \hline \multicolumn{1}{c|}{ Statement } & SD & D & A & SA & Mean & \multirow{2}{*}{ SD } \\
\cline { 2 - 4 } & $\mathbf{N ~ ( \% )}$ & $\mathbf{N ~ ( \% )}$ & $\mathbf{N ~ ( \% )}$ & $\mathbf{N ~ ( \% )}$ & $(\overline{\boldsymbol{X}})$ & \\
\hline \hline I have consumed alcohol beforehand & $686(92.9)$ & $17(2.3)$ & $15(2.0)$ & $18(2.4)$ & 1.50 & 1.73 \\
I started drinking alcohol since I was 13 years old. & $667(90.5)$ & $33(4.5)$ & $21(2.8)$ & $16(2.2)$ & 1.50 & 1.67 \\
I had a can of alcohol since the last 30 days & $643(87.1)$ & $48(6.5)$ & $28(3.8)$ & $19(2.6)$ & 1.59 & 1.75 \\
I had too much of alcohol since the last 30 days & $632(85.5)$ & $51(6.9)$ & $31(4.2)$ & $21(2.8)$ & 1.59 & 1.72 \\
I did buy alcoholic drink for the last 30 days & $674(91.5)$ & $29(3.9)$ & $19(2.6)$ & $15(2.0)$ & 1.51 & 1.72 \\
I have used inhalant drugs beforehand (sniff) & $677(91.7)$ & $28(3.8)$ & $16(2.2)$ & $17(2.3)$ & 151 & 1.72 \\
I have used hallucinating drugs beforehand. & $684(92.6)$ & $24(3.3)$ & $11(1.5)$ & $19(2.6)$ & 1.53 & 1.78 \\
\hline
\end{tabular}

Pertaining to the issue of alcohol consumption among the students, most of the students surveyed had indicated "Never" and "Seldom" on all items. However, a small number of students indicated that they "Always" and "Sometimes" on item "I have consumed alcohol beforehand" $(n=19(3.2 \%))$. For items such as "I had a can of alcohol since the last 30 days", "I had too much of alcohol since the last 30 days" and "I did buy alcoholic drink for the last 30 days", less than $1 \%$ of the students surveyed had indicated that they "Strongly agree" and "Agree" on these items.

As for the drug intake among students surveyed, only 33 (4.5) of the students surveyed had indicated "Strongly agree" and "Agree" on the item "I have used inhalant drugs beforehand (sniff)". In addition, only 30 (4.1\%) of the students surveyed had indicated "Strongly agree" and "Agree" on the item "I have used hallucinating drugs beforehand".

In addition to the above findings, students were also asked to provide perceived reasons for alcohol or drug intake. The following Table 10 tabulates the reasons given by students based on number of students who had "Strongly agree" and "Agree" on the statements provided.

\section{Question 2: Attributing Factors of At-Risk Behaviors as Perceived by Respondents}

As regard to the possible attributing factors for alcohol and substance abuse, only a handful respondent wrote reasons qualitatively for tobacco and substance abuse and it was just based on their perceptions. Table 10 indicated the possible reasons for alcohol and substance abuse as perceived by the respondents of this study. 
Table 10: Reasons for Alcohol and Substance Abuse

\begin{tabular}{lcc}
\hline \hline \multicolumn{1}{c}{ Reasons } & $\mathrm{N}$ & $\%$ \\
\hline \hline Family problems. (eg.: divorce/siblings rivalry) & 7 & 1.10 \\
Problems with partner/separation with partner/woman & 7 & 1.10 \\
Feel aroused/feel excited/wanted to try \& looking for experience & 7 & 1.10 \\
Peer influence/wanted to be accepted by peer & 6 & 1.00 \\
Electronic and printed media influences & 7 & 1.10 \\
Lacked of parental education and information from teachers. & 7 & 1.10 \\
\hline \hline
\end{tabular}

Basically the reasons for alcohol and substance abuse were attributed by adolescents' inability to cope with family problems namely divorce or sibling rivalry, separation with intimate partner(s), sense of curiosity or excitement, peer acceptance and pee rejection, influences that came from electronic and printed media and lacked of guidance and information from parents and teachers in school. However these reasons didn't represent the entire sample as the percentage (1.10\%) for each reason was very small indeed.

Table 11: Suicide Ideation and Suicide Attempt

\begin{tabular}{c|c|c|c|c}
\hline \hline \multirow{2}{*}{ Statement } & SD & $\mathrm{D}$ & $\mathrm{A}$ & $\mathrm{SA}$ \\
\cline { 2 - 5 } & $\mathrm{n}(\%)$ & $\mathrm{n}(\%)$ & $\mathrm{n}(\%)$ & $\mathrm{n}(\%)$ \\
\hline \hline Had serious suicide ideation for the last 12 months & $662(89.8)$ & $38(5.1)$ & $20(2.7)$ & $18(2.4)$ \\
Had attempted suicide once for the last 12 months & $712(96.4)$ & $10(1.4)$ & $8(1.1)$ & $8(1.1)$ \\
\hline \hline
\end{tabular}

$$
n=738
$$

This section utilized the Likert scale which ranged from Strongly Agree (SA) - 5 to the lowest (Strongly Disagree) - SD 1 point. Among all the students surveyed, 38 (5.1\%) students had indicated "Strongly Agree" and "Agree" on the item related to "Has serious thought of committing suicide" and 16 (2.2\%) students had indicated Strongly Agree" and "Agree" on the item "Had attempted suicide once". Attention need to be given to suicide ideation and suicide attempt found among these respondents as it highlighted that 54 students were having suicide ideations and made suicide attempt from the total number of respondents examined by this study. The following table indicated the perceived reasons for youngsters to have the tendency to have suicide ideation and make suicide attempts.

Table 12: Possible reasons for suicide ideation and attempt as perceived by secondary school students

\begin{tabular}{lcc}
\hline \multicolumn{1}{c}{ Reasons } & $\mathrm{N}$ & $\%$ \\
\hline Emotionally disturbed due to some kind of frustration (eg. Failing in examination) & 7 & $1.10 \%$ \\
Felt so ashamed / sad (made fun by friends) & 5 & $0.80 \%$ \\
Lost loved objects / pets / friends & 5 & $0.80 \%$ \\
Sexual harassment by close family members or classmates (via vulgar nicknames) & 6 & $0.10 \%$ \\
\hline
\end{tabular}

\section{Premarital Sex Orientation}

Descriptive analysis was employed to ascertain activities related sexual relationship among the Malaysian adolescents. The findings were depicted in Table 13.

Table 13: Premarital Sex Orientation

\begin{tabular}{lcccc}
\hline \multicolumn{1}{c}{ Items } & Never (\%) & Once (\%) & Twice (\%) & Frequent (\%) \\
\hline Have had premarital sex & $648(87.8)$ & $18(2.4)$ & $48(6.5)$ & $24(3.3)$ \\
Had premarital sex after 13 years old & $651(88.2)$ & $14(1.9)$ & $40(5.4)$ & $33(4.5)$ \\
Had once been infected by STD due to my sexual relationships & $642(86.4)$ & $11(1.5)$ & $54(7.3)$ & $35(4.7)$ \\
Became pregnant due to my sexual relationship & $660(89.4)$ & $8(1.1)$ & $53(7.2)$ & $17(2.3)$ \\
Have had an abortion & $660(89.4)$ & $5(0.7)$ & $55(7.5)$ & $18(2.4)$ \\
\hline
\end{tabular}

$$
\mathrm{N}=738
$$


Five items were utilized to examine premarital sex among secondary school adolescents. About $87.8 \%$ of the respondents admitted that they never had premarital sex before as opposed to 24 (3.3\%) frequently had premarital sex. Comparatively 651 (88.2\%) never had premarital sex even after 13 years old as opposed to 33 (4.5) of them who frequently had premarital sex. On the contrary $642(86.4 \%)$ of the students had never been infected by STD and 35 (4.7\%) had been frequently infected by STD. As for teen pregnancy, 660 (89.4\%) of the students were never pregnant as compared to $17(2.3 \%)$ of them. As for abortion, 660 (89.4\%) never had abortion as opposed to 18(2.4\%) who had several abortions.

\section{Runaways}

Similarly, descriptive statistics namely frequency counts and percentages were employed to examine students' runaway history. Findings of this analysis were tabulated in Table 14 below.

Table 14: Runaway from Home

\begin{tabular}{|c|c|c|c|c|}
\hline Items & SD \% & D \% & A \% & SA $\%$ \\
\hline Runaway history - 2/more times & $712(96.48)$ & $23(3.12)$ & $3(6.41)$ & 0 \\
\hline Runaway attempt - 2/more times & $697(94.44)$ & $32(4.34)$ & $7(0.95)$ & $2(0.27)$ \\
\hline
\end{tabular}

Table 14 indicated that only (3) $6.41 \%$ of the respondents indicated history of run away from home more than once while only $9(1.22 \%)$ reported that they made more than 2 runaway attempts. Majority of the respondents strongly disagree or opposed the concept of runaway and making runaway attempts.

\section{Causes of Runaways as Perceived by Respondents}

Table 15 tabulates findings on causes of runaway among Malaysian adolescents. These scores were tabulated in frequency counts and percentages.

Table 15: Causes of Runaway as Perceived by Respondents

\begin{tabular}{lcccc}
\hline \multicolumn{1}{c}{ Items } & SD \% & D \% & A \% & SA \% \\
\hline Peer influence & $644(87.27)$ & $37(5.01)$ & $31(4.20)$ & $26(3.52)$ \\
Having fun & $620(84.01)$ & $51(6.911)$ & $47(6.37)$ & $20(2.7)$ \\
Alcohol addiction & $680(92.14)$ & $20(2.71)$ & $24(3.52)$ & $14(1.90)$ \\
Drug addiction & $684(92.68)$ & $7(0.95)$ & $26(3.52)$ & $21(2.85)$ \\
Follow boy / girl friend & $664(89.97)$ & $17(2.30)$ & $25(3.39)$ & $32(4.34)$ \\
Fought with parents & $614(83.20)$ & $58(7.86)$ & $41(5.56)$ & $25(3.39)$ \\
Fought with siblings & $596(80.76)$ & $75(10.16)$ & $54(7.32)$ & $13(1.76)$ \\
Lost interest in study & $637(86.31)$ & $50(6.78)$ & $36(4.88)$ & $15(2.03)$ \\
Fear of threats & $651(82.21)$ & $41(5.56)$ & $30(4.07)$ & $16(2.17)$ \\
Were punished / humiliated & $650(88.08)$ & $51(6.91)$ & $23(3.12)$ & $14(1.90)$ \\
Uncomfortable house / home - small size & $671(90.92)$ & $31(4.20)$ & $22(2.98)$ & $14(1.90)$ \\
had premarital sex and was pregnant & $683(92.55)$ & $9(1.22)$ & $19(2.57)$ & $27(3.66)$ \\
Sexually harassed by significant others & $682(92.41)$ & $14(1.90)$ & $21(2.85)$ & $21(2.85)$ \\
Fear of police due to involvement in illegal gang & $677(91.73)$ & $16(2.17)$ & $26(3.52)$ & $19(2.57)$ \\
Found jobs - to earn extra money & $658(89.16)$ & $29(3.93)$ & $26(3.52)$ & $25(3.39)$ \\
\hline
\end{tabular}

$$
\mathrm{N}=738
$$

The above table demonstrates that the highest causes of runaway (between $11.2 \%$ and $11.4 \%$ ) as perceived by the respondents and were attributed by personal, internal and external factors. Personal factors ranged from fun searching, experimenting with drug and alcohol, lost interest in study, lost self-esteem, in love, fear of threats and wanting independent and to earn money. As for external factor, they ranged from home environment, sibling rivalry, incest and sexual harassment, family disputes and divorce. However these personal, internal and external reasons for runaways were isolated cases and small in terms of their percentages. Majority of the respondents were either strongly disagree and disagree with other statements. 


\section{Abortion and Baby Abandonment}

Majority of the respondents reported that they disagree or strongly disagree with the issue of abortion (99.59\%) and attempt of abortion (99.73\%) as opposed to the percentage of agree and strongly agree with "had abortion" and "had tried abortion". There is still strong awareness with regard to the rights of significant others to live.

Table 16: Abortion and Baby Abandonment

\begin{tabular}{lcccc}
\hline \multicolumn{1}{c}{ Items } & SD \% & D \% & A \% & SA \% \\
\hline Had abortion & $735(99.59)$ & $2(0.3)$ & $1(0.13)$ & 0 \\
Had tried to abort pregnancy & $734(99.46)$ & $2(0.27)$ & $2(0.27)$ & 0 \\
\hline 738 & & &
\end{tabular}

\section{Causes of Pregnancy as Perceived by Respondents}

The following were causes of teen pregnancy as perceived by the respondents and were tabulated in Table 17.

Table 17: Causes of Pregnancy as Perceived by Respondents

\begin{tabular}{|c|c|c|c|c|}
\hline Items & SD \% & D \% & A \% & SA $\%$ \\
\hline Influenced by porno film & $580(78.59)$ & $24(3.25)$ & $106(14.36)$ & $28(3.79)$ \\
\hline Had frequent sexual relationship with boyfriend without prevention measures. & $592(80.22)$ & $11(1.49)$ & $99(13.41)$ & $36(4.88)$ \\
\hline Sex addiction/unable to control sexual desire. & $587(79.54)$ & $19(2.57)$ & $90(12.20)$ & $42(5.69)$ \\
\hline Rape victim & $591(80.08)$ & $17(2.30)$ & $96(13.01)$ & $34(4.61)$ \\
\hline Involved in prostitution & $596(80.76)$ & $10(1.36)$ & $94(12.74)$ & $38(5.15)$ \\
\hline
\end{tabular}

The table above indicated that the main causes of teen pregnancy as perceived by the respondents were attributed by pornography influences (18.15\%), sexual relationship without prevention measures (18.29\%), addiction to sex (17.89\%), rape victim (17.62\%) and involvement in prostitution (17.89\%).

\section{Causes of Abortion as Perceived by Respondents}

Table 18: Causes of Abortion as Perceived by Respondents

\begin{tabular}{lcccc}
\hline \multicolumn{1}{c}{ Items } & SD \% & D \% & A \% & SA \% \\
\hline Aborted - ashamed with parents/friends/community & $585(79.27)$ & $21(2.85)$ & $86(11.65)$ & $46(6.23)$ \\
Aborted - fear if discovered by parents/school/peers/ neighbors & $586(79.40)$ & $15(2.03)$ & $84(11.38)$ & $53(7.18)$ \\
Aborted - boyfriend refused to be responsible & $588(79.67)$ & $17(2.30)$ & $89(12.06)$ & $44(5.96)$ \\
Aborted - not prepared to be a mother & $587(79.54)$ & $29(3.93)$ & $92(12.47)$ & $30(4.07)$ \\
Aborted - forced by boyfriend & $589(79.81)$ & $18(2.44)$ & $88(11.92)$ & $43(5.83)$ \\
\hline N=738 & & & &
\end{tabular}

Table 18 tabulates respondents' perceptions on the causes of abortion and was perceived as being attributed by the feeling of shame towards others (17.88\%), fear of being discovered by parents/ school/ peers/ neighbors (18.56\%), boyfriend's refusal to take responsibility (18.02\%), not prepared to be young mothers (16.54\%) and forced by boyfriend (17.75\%).

\section{Research Question 3: Anova Analyses}

Are there significant differences in premarital sex orientation as regard to the following"

a. Family SES

b. Student's background (urban versus rural)

c. Parents' marital statuses

Comparison on adolescents' selected at-risk behaviors namely smoking patterns, alcohol and substance abuse, suicide ideation and suicide attempts and premarital sex orientation was made using ANOVA and the findings were tabulated as the following: 
Table 19: Comparison of Smoking Patterns by Age, Family SES, and Parents' marital Statuses

\begin{tabular}{|c|c|c|c|c|c|c|c|c|c|}
\hline Variable & & $\mathrm{N}$ & Mean & SD & $d f$ & SS & MS & $F$ & $P$ \\
\hline \multirow{5}{*}{ Age groups } & 13 & 82 & 2.52 & 1.89 & & & & & \\
\hline & 14 & 193 & 2.52 & 1.48 & & & & & \\
\hline & 15 & 230 & 2.42 & 1.44 & & & & & \\
\hline & 16 & 91 & 2.40 & 1.69 & & & & & \\
\hline & 17 & 142 & 1.98 & 1.73 & & & & & \\
\hline Btw. Groups & & & & & 4 & 28.41 & 7.10 & \multirow[b]{2}{*}{2.80} & \multirow[b]{2}{*}{$.030^{*}$} \\
\hline Within Groups & & & & & 733 & 1860.100 & 2.54 & & \\
\hline \multirow{3}{*}{ Family SES } & High & 94 & 245 & 155 & & & & & \\
\hline & Average & 233 & 2.51 & 1.44 & & & & & \\
\hline & Low & 390 & 2.23 & 1.59 & & & & & \\
\hline $\begin{array}{c}\text { Btw } \\
\text { Groups }\end{array}$ & & & & & 3 & 26.38 & 8.79 & \multirow[t]{2}{*}{3.46} & \multirow[t]{2}{*}{$.020^{\star}$} \\
\hline Within Groups & & & & & 734 & 1863.0 & 2.54 & & \\
\hline \multirow{4}{*}{ Parents' marital Statuses } & Married & 648 & 2.40 & 1.64 & & & & & \\
\hline & Divorced & 52 & 1.95 & 1.07 & & & & & \\
\hline & Separated & 10 & 2.41 & 1.23 & & & & & \\
\hline & Cohabitated & 12 & 2.49 & 1.30 & & & & & \\
\hline Btw Groups & & & & & 6 & 16.07 & 2.68 & 1.05 & .400 \\
\hline Within Groups & & & & & 731 & 1873.3 & 2.56 & & \\
\hline
\end{tabular}

*Significant at $p<.05$

Table 19 tabulates findings on ANOVA analysis on adolescent's smoking patterns by respondents' age, family SES and parents' marital status. Adolescents' smoking patterns were compared based on their age groups via ANOVA analysis. The only significant differences in adolescents' smoking patterns were found in adolescents age groups, $F(4,733)=7.44$, $p=.000$. The mean score was higher for the age groups of 13 through 14 years old respectively.

Table 20: Comparison of alcohol \& substance abuse by Age, Family SES, and Parents' marital Statuses

\begin{tabular}{|c|c|c|c|c|c|c|c|c|c|}
\hline Variable & & $\mathrm{N}$ & Mean & SD & $d f$ & SS & $M S$ & $F$ & $P$ \\
\hline \multirow{5}{*}{ Age groups } & 13 & 82 & 1.55 & 1.77 & & & & & \\
\hline & 14 & 193 & 1.26 & 1.05 & & & & & \\
\hline & 15 & 230 & 1.35 & 1.21 & & & & & \\
\hline & 16 & 91 & 1.55 & 1.68 & & & & & \\
\hline & 17 & 142 & 2.16 & 2.48 & & & & & \\
\hline Btw. Groups & & & & & 4 & 77.94 & 19.50 & \multirow{2}{*}{7.44} & \multirow{2}{*}{$.00^{*}$} \\
\hline Within Groups & & & & & 733 & 1921.0 & 2.62 & & \\
\hline & & & & & & & & & \\
\hline \multirow{3}{*}{ Family SES } & High & 94 & 1.81 & 2.13 & & & & & \\
\hline & Average & 233 & 1.56 & 1.74 & & & & & \\
\hline & Low & 390 & 1.41 & 1.34 & & & & & \\
\hline $\begin{array}{c}\text { Btw } \\
\text { Groups }\end{array}$ & & & & & 3 & 24.54 & 8.18 & \multirow[t]{2}{*}{3.04} & \multirow[t]{2}{*}{$.030^{*}$} \\
\hline Within Groups & & & & & 734 & 1974.4 & 2.69 & & \\
\hline \multirow{5}{*}{ Parents' marital Statuses } & & & & & & & & & \\
\hline & Married & 648 & 1.56 & 1.72 & & & & & \\
\hline & Divorced & 52 & 1.25 & .453 & & & & & \\
\hline & Separated & 10 & 1.20 & .363 & & & & & \\
\hline & Cohabitated & 12 & 1.143 & .298 & & & & & \\
\hline Btw Groups & & & & & 6 & 13.63 & 2.27 & .84 & .54 \\
\hline Within Groups & & & & & 731 & 1985.3 & 2.72 & & \\
\hline
\end{tabular}

As regard to alcohol and substance abuse, significant differences were found in adolescents' age groups $F(4,733)=7.44$, $p=.00$. and family SES, and Parents' marital Statuses $F(3,734)=.030$ respectively. As regard to alcohol and substance abuse, the mean scores were higher for respondents whose ages were 17, 13 and 16 years old respondents. 
Table 21: Comparison of Speeding, Suicide Ideation \& Suicide Attempt and eating disorder by Age, Family SES, and Parents' marital Statuses

\begin{tabular}{|c|c|c|c|c|c|c|c|c|c|}
\hline Variable & & $\mathrm{N}$ & Mean & SD & $d f$ & SS & $M S$ & $F$ & $P$ \\
\hline \multirow{5}{*}{ Age groups } & 13 & 82 & 1.92 & 2.08 & & & & & \\
\hline & 14 & 193 & 2.31 & 2.19 & & & & & \\
\hline & 15 & 230 & 2.71 & 2.31 & & & & & \\
\hline & 16 & 91 & 2.53 & 2.16 & & & & & \\
\hline & 17 & 142 & 2.92 & 2.45 & & & & & \\
\hline Btw. Groups & & & & & 4 & 69.24 & 17.31 & \multirow{2}{*}{3.37} & \multirow{2}{*}{$.010^{\star}$} \\
\hline Within Groups & & & & & 733 & 3769.9 & 5.14 & & \\
\hline & & & & & & & & & \\
\hline \multirow{3}{*}{ Family SES } & High & 94 & 1.81 & 2.13 & & & & & \\
\hline & Average & 233 & 1.56 & 1.74 & & & & & \\
\hline & Low & 390 & 1.41 & 1.34 & & & & & \\
\hline $\begin{array}{c}\text { Btw } \\
\text { Groups }\end{array}$ & & & & & 3 & 43.03 & 14.34 & \multirow[t]{2}{*}{2.77} & \multirow[t]{2}{*}{$.041^{*}$} \\
\hline Within Groups & & & & & 734 & 3796 & 5.17 & & \\
\hline & & & & & & & & & \\
\hline \multirow{4}{*}{ Parents' marital Statuses } & Married & 648 & 2.55 & 2.30 & & & & & \\
\hline & Divorced & 52 & 2.45 & 2.04 & & & & & \\
\hline & Separated & 10 & 1.67 & 1.80 & & & & & \\
\hline & Cohabitated & 12 & 1.94 & 1.98 & & & & & \\
\hline Btw Groups & & & & & 6 & 38.98 & 6.50 & \multirow{2}{*}{1.25} & \multirow{2}{*}{.280} \\
\hline Within Groups & & & & & 731 & 3800.2 & 5.20 & & \\
\hline
\end{tabular}

Similar comparison via ANOVA was made on respondents' perception of motor speeding, suicide ideation and suicide attempt and eating disorder. Significant differences were found in respondents' age group: $F(4,733)=3.37, p=.01$ and family SES; $F(3,734)=2.77, p=.041$. Higher mean score were found amongst 17 years old right through 15 years old respondents. Similarly the highest mean score was found amongst respondents from the high SES background as regard to motor speeding, suicide ideation and suicide attempt and eating disorder.

Table 22: Comparison of Premarital Sex Orientation by Age, Family SES, Parents' marital Statuses

\begin{tabular}{|c|c|c|c|c|c|c|c|c|c|}
\hline Variable & & $\mathrm{N}$ & Mean & SD & $d f$ & SS & $M S$ & $F$ & $P$ \\
\hline \multirow{5}{*}{ Age groups } & 13 & 82 & 3.00 & 1.48 & & & & & \\
\hline & 14 & 193 & 2.81 & .86 & & & & & \\
\hline & 15 & 230 & 2.62 & 1.17 & & & & & \\
\hline & 16 & 91 & 2.97 & 1.21 & & & & & \\
\hline & 17 & 142 & 3.49 & 1.73 & & & & & \\
\hline Btw. Groups & & & & & 4 & 70.1 & 17.52 & \multirow{2}{*}{10.82} & \multirow{2}{*}{$.00^{*}$} \\
\hline Within Groups & & & & & 733 & 1186.7 & 1.62 & & \\
\hline & & & & & & & & & \\
\hline \multirow{3}{*}{ Family SES } & High & 94 & 3.13 & 1.47 & & & & & \\
\hline & Average & 233 & 2.82 & 1.38 & & & & & \\
\hline & Low & 390 & 1.14 & 1.14 & & & & & \\
\hline $\begin{array}{c}\text { Btw } \\
\text { Groups }\end{array}$ & & & & & 3 & 7.22 & 2.41 & \multirow[b]{2}{*}{1.41} & \multirow[b]{2}{*}{.24} \\
\hline Within Groups & & & & & 1249.6 & 1249.6 & 1.70 & & \\
\hline & & & & & & & & & \\
\hline \multirow{4}{*}{ Parents' marital Statuses } & Married & 648 & 2.95 & 1.35 & & & & & \\
\hline & Divorced & 52 & 2.62 & .65 & & & & & \\
\hline & Separated & 10 & 2.72 & .790 & & & & & \\
\hline & Cohabitated & 12 & 2.49 & .950 & & & & & \\
\hline Btw Groups & & & & & 6 & 14.52 & 2.42 & \multirow[b]{2}{*}{1.42} & \multirow[b]{2}{*}{.203} \\
\hline Within Groups & & & & & 731 & 1242.3 & 1.70 & & \\
\hline
\end{tabular}

*Significant at $P<.05$ 
Table 22 tabulates findings on ANOVA analysis of adolescent's premarital sex orientation. This comparison was made by considering respondents' age groups, family SES and parent(s) marital statuses. The findings indicated that significant difference was only found in respondents' age groups $F(4,733)=10.82$, at $p=.000$ and not for Family SES and parents' marital statuses. The mean score indicated higher mean score for adolescents whose age groups were between 13 and 14 years old respectively. This suggests the "storm and stress" period are experienced by many adolescents and as well developmental progression in age which have some effect on adolescents involvement in premarital sex.

\section{Findings from $T$-Test Analysis}

$t$-test analysis were executed to examine significant gender and location differences as regard to smoking patterns among the Malaysian adolescents. Findings from the $t$-test analysis were tabulate in Table 23

Table 23: Comparison of smoking patterns by gender and respondents' location via t-tests Analysis

\begin{tabular}{cccccccc}
\hline Variable & & $\mathrm{N}$ & Mean & Std. Deviation & $t$ & $d f$ & $P$ \\
\hline \multirow{2}{*}{ Gender } & Male & 301 & 3.12 & 1.61 & \multirow{2}{*}{12.84} & 705 & \multirow{2}{*}{$.000^{*}$} \\
& Female & 406 & 1.76 & 1.20 & & & \\
\multirow{2}{*}{ Location } & Rural & 278 & 2.07 & 1.26 & 4.04 & 736 & $.000^{*}$ \\
\hline \multirow{2}{*}{ *the mean difference is significant at $p<.05$} & Urban & 460 & 2.55 & 1.75 & & &
\end{tabular}

T-test analyses indicated that significant gender differences were found between male and female in teen smoking patterns; $(p=.000)$. Male had higher mean scores compared to female. Similarly significant differences were found in the respondents' location where urban respondents had higher mean scores than their rural counterparts $(p=.000)$.

Table 24: Comparison of Alcohol and Substance Abuse patterns by gender and respondents' location via t-tests Analysis

\begin{tabular}{|c|c|c|c|c|c|c|c|}
\hline Variable & & $\mathrm{N}$ & Mean & Std. Deviation & $t$ & $d f$ & $P$ \\
\hline \multirow{2}{*}{ Gender } & Male & 301 & 1.42 & 1.43 & \multirow[b]{2}{*}{-.84} & \multirow{2}{*}{705} & \multirow{2}{*}{.403} \\
\hline & Female & 406 & 1.51 & 1.60 & & & \\
\hline \multirow{2}{*}{ Location } & Rural & 278 & 1.57 & 1.75 & \multirow{2}{*}{-.55} & \multirow{2}{*}{736} & \multirow{2}{*}{.579} \\
\hline & Urban & 460 & 1.51 & 1.58 & & & \\
\hline
\end{tabular}

$T$-test analyses was undertaken to examine significant gender and location differences in alcohol and substance abuse patterns. The findings indicated that no significant gender $(p=.403)$ and location $(p=.579)$ differences were found in alcohol and substance abuse.

Table 24: Comparison of Motor Speeding, Suicide Ideation \& Suicide Attempt and eating disorder by gender and student's location

\begin{tabular}{cccccccc}
\hline Variable & & $\mathrm{N}$ & Mean & Std. Deviation & $t$ & $d f$ & $P$ \\
\hline \multirow{2}{*}{ Gender } & Male & 301 & 3.79 & 2.48 & \multirow{2}{*}{14.69} & 705 & $.000^{*}$ \\
& Female & 406 & 1.58 & 1.49 & & & \\
\multirow{2}{*}{ Location } & Rural & 460 & 2.44 & 2.23 & .21 & 736 & .35 \\
& Urban & 278 & 2.60 & 2.32 & & \\
\hline
\end{tabular}

As regard to motor speeding, suicide ideation and suicide attempt, t-test analyses was undertaken to examine significant gender and location differences in them. The findings showed that significant gender differences $(p=.000)$ were found in suicide ideation, suicide attempt and eating disorder. Male had higher mean scores as opposed to female. no significant location differences $(p=.35)$ were found between students who came from rural or urban schools. On the contrary, significant gender differences $(p=.000)$ were found between male and female respondents. 
Table 25: Comparison of premarital sex orientation by gender and respondents' location via t-tests Analysis

\begin{tabular}{llllllll}
\hline Variable & & $\mathrm{N}$ & Mean & Std. Deviation & $t$ & $d f$ & $P$ \\
\hline Gender & Male & 301 & 2.89 & 1.11 & .204 & 705 &. .84 \\
& Female & 406 & 2.87 & .1 .30 & & & \\
\multirow{2}{*}{ Location } & Rural & 278 & 3.03 & 1.24 & -1.80 & 736 & .072 \\
& Urban & 460 & 2.86 & 1.34 & & & \\
\hline
\end{tabular}

Table 25 shows that no significant gender differences was found in adolescents' premarital sex orientation $(p=.84)$. Inspection of the two groups indicated that the differences in mean scores were small. Similarly inspections on the students' location indicated no significant difference $(p=.072)$ in adolescents' premarital sex orientation that either come from rural or urban areas.

\section{Discussion and Conclusion}

With respect to adolescents' at-risk behaviors which have been identified by previous studies and ascertained by this study, with respect to smoking habits, majority of the respondents disagreed with the smoking habits. In spite of the respondents' positive attitude, small percentages of the respondents reported that they had smoked before. This fact should not be dismissed and attentive measures are necessary so as to curb smoking habits among the Malaysian adolescents. It was also notable that majority of the respondents were also against alcohol consumption and substance abuse except for a few minorities. Findings on drug abused revealed that majority of the respondents disagreed with drug abused except for a handful of respondents. Similarly, majority of the respondents were against motor speeding, suicide ideation and suicide attempt and eating disorder except for small percentages of the respondents were for this lifestyle. As for premarital sex orientation, majority of the respondents examined were not in favor of this lifestyle which is perceived as health hazard. Even though only small percentages of the respondents embraced such lifestyle, attention must be given to these unhealthy and devastating practices. Adolescents are the country's future stakeholders and they will be assuming the country's leadership in the near future. Thus, exemplary roles models among Malaysian adolescents must be generated from the current pool of adolescents in this country. The current political leadership, NGOs, school, community and parents must work hand in hand to realize these aims and objectives of producing future leaders who are highly competent, conversant, creative and innovative, charismatic and holistically developed to serve the noble aims of education of this country. Hence joint efforts must be taken to rule out these negative elements in schools and homes. In summary, at-risk behaviors among secondary school students are relatively low. Nevertheless preventive measures as well as appropriate intervention strategies are needed to minimize the occurrence of at-risk behaviors among Malaysian adolescents and to produce mentally and physically healthy adolescents who will pave and lead the country's future..

\section{Future Research}

Findings from this study can be used as parameters for developing modules and inventories for examining at-risk behaviors among the Malaysian youngsters based on Malaysian norms. Future research on similar area may include new variables such social media addiction (video-gaming), truncy, gangsterism and bullying, participation of youth in misconceived "jihad" and international terrorism.

\section{References}

Al-Sadat, N., Misau, A. Y., Zarihah, Z., Maznah, D., \& Tin Su, T. (2010). Adolescent tobacco use and health in Southeast Asia. AsiaPacific Journal of Public Health, Supplement to 22 (3) 1755 -180S.

Arredondo, D. E. (2003). Child development, children's mental health and the juvenile justice system: Principles for effective decisionmaking. Stanford Law \& Policy Review, 14(1), 13-28.

Barnes, G. M., Hoffman, J. H., Welte, J. W., Farrell, M. P., \&Dintcheff, B. A. (2006). Effects of parental monitoring and peer deviance on substance use and delinquency.Journal of Marriage and Family, 68, 1084-1104.

Baumrind, D. (1991).Effective parenting during the early adolescent transition. In Cowan, P. E. and Hetherington, E.M. (eds), Advances in Family Research. Erlbaum, Hillsdale, NJ, pp. 111-163.

Bearinger, L. H., Sieving, R. E., Ferguson, J., \& Sharma, V. (2007). Global perspectives on the sexual and reproductive health of adolescents: Patterns, prevention, and potential. The Lancet, 369(9568), 1220-1231.

Blumstein, A., Farrington, D., \& Moitra, S. (1985). Delinquency careers: innocents, desisters, and persisters. In Crime and Justice (ed. M. 
Tonry\& N. Morris). Chicago, IL: University of Chicago Press.

Brooks-Gunn, J., Petersen, A. C. and Eichorn, D. (1985). The study of maturational timing effects in adolescence. Specialissues.Journal of Youth and Adolescence, 14(3), 4-8.

Cheung-Blunden, V., \&Juang, L. (2008). Expanding acculturation theory: Are acculturation models and the adaptiveness of acculturation strategies generalizable in a colonial context? International Journal of Behavioral Development, 32, 21-33.

Chiah, Y. W., \&Baharudin, R. (2012). Temperament and parental attachment on early adolescents' socio-emotional adjustments. EBSCO HOST, DOI: 10.7763/IPEDR, V48.12

Choi, Y., \&Lahey, B. B. (2006).Testing the model minority stereotype: Youth behaviors across racial and ethnic groups.Social Service Review, 80, 419-452.

Dadds, M. R., Sanders, M. R., Morrison, M., \&Rebgetz, M. (1992). Childhood depression and conduct disorder: II. An analysis of family interaction patterns in the home. Journal of Abnormal Psychology, 101, 505-513.

David, K. M., \& Murphy, B. C. (2004). Inter-parental conflict and late adolescents; sensitization to conflict: The moderating effects of emotional functioning and gender. Journal of Youth and Adolescence, 33(3), 187-200.

Dryfoos, J. D. (1990) Adolescents at Risk: prevalence and prevention. Oxford University Press, New York.

Fauziah, I., Mohamad, M. S., Chong, S. T., \& Abd Manaf, A. (2012). Substance abuse and aggressive behavior among adolescents. Asian Social Science, Vol. 8, No. 9.

Feldman, S. S. and Elliot, G. R. (eds) (1990) At the threshold: The developing adolescent. Harvard University Press,Cambridge.

Feldman, S.S., Rosenthal, D.A., Mont-Reynaud, R., Lau, S., \& Leung, K. (1991).Anti social behavior: Adolescent values and family environments as correlates of misconduct in Australia, Hong Kong, and the United States. Journal of Research in Adolescence, 1, 109-134.

Fendrich, M., Weissman, M. M., \& Warner, V. (1991).Longitudinal assessment of major depression and anxiety disorders in children.Journal of the Academy of Child and Adolescent Psychiatry, 30, 38-42.

Furstenburg, F. F. (1991) Coming of age in a changing family system. In Feldman, S. S. and Elliot, G. R. (eds), At theThreshold: The Developing Adolescent. Harvard University Press, Cambridge, pp. 1-14.

Greenberger, E., Chen, C., Beam, M., Sang-Min Wang, S.,\& Dong, Q. (2000). The perceived social contexts of adolescents' misconduct: A comparative study of youths in three cultures. Journal of Research on Adolescence. Vol. 10, Issue, 3, DOl:

10.1207/SJRA10037

Haddad, J., Barocas, R., \&Hallenbeck, A. (1991). Family organization and parent attitudes of children with conduct disorder. Journal of Clinical Psychology, 20, 152-161.

Hamzah, H., \& Mustafa, J. M (no d.).Driving factors of social misconduct amongst secondary school students in Melaka Tengah district.Retrieved Febrauary 12, 2013 from intra.hukm.ukm.my/...\%20nutrition\%20and\%20social\%20work/03.

Hawkins, J. D. and Weis, J. G. (1985). The social development model: an integrated approach to delinquency prevention.Journal of Primary Prevention, 6, 73-97.

Herrenkohl, T. I., Tajima, E. A., Whitney, S. D., \& Huang, B. (2005). Protection against antisocial behavior in children exposed to physically abusive discipline. Journal of Adolescent Health, 36,457-465.Retrieved January 11, 2011 from ScienceDirect database.

Hidayah, N. I., Hanafiah, M.S., Idris, M.N., Rasnah, S., Ibrahim, N.M.S., \& Nonnah, C.D. (2003). Risk behavior amongst adolescents of a rural land development scheme in peninsular Malaysia. Jurnal Kesihatan Masyarakat, Jilid, 9.

Hishinuman, S. E., Johnson, C.R., Kim, P. S., Nishimura, T. S., Makini, K. G., Andrade, N. N., Yates, A., Goebert, A.D., Mark, Y.G., Mayeda, T. D., \& Revilla, A. L. (2005). Prevalence and correlates of misconducts among ethnically diverse adolescents of native Hawaiian/part Hawaiian and non-Hawaiin ancestry. International Journal of Social Psychiatry, Sage Publication, DOI: 10.1177/0020764005057371

Hoge, R. D., Andrews, D. A., \&Leschied, A. W. (1994).Tests of three hypotheses regarding the predictors of delinquency. Journal of Abnormal Child Psychology, 22, 547-559.

Homma, Y., Chen, W., Poon, C. S., \& Saewyc, E. M. (2012). Substance use and sexual orientation among east and southeast Asian adolescents in Canada. Journal of Child Adolescent Substance Abuse.

Hongsranagon, P., Khompratya, T., Hongpukdee, S., Havanond, P., \& Deelertyuenyong, N. (2011). Traffic risk behavior and perceptions of Thai motorcyclists: A case study. Elsevier, Science Direct Publication.

Jambulingam, M., Thuraisingam, A. S., \& Rajagopal, G. R. (2013). Salient factors influencing the healthy development of adolescents. Australian Journal of Basic and Applied Sciences, 7(8): 561-564.

Jemmott, L. S., \& Jemmott, J. B. (1990). Sexual knowledge, attitudes, and risky sexual behavior among inner-city black male adolescents. Journal of Adolescent Research, 5(3), 346-369.

Jessor, R., Turbin, M. S., Costa, F. M., Dong, Q., Zhang, H., \& Wang, C. (2003). Adolescent problem behavior in China and the United States: A cross-national study of psychosocial protective factors. Journal of Research on Adolescence, 13, 329-360.

Juang, L. \& Nguyen, H. (2009). Misconduct among Chinese American adolescents: The role of acculturation, family obligation, and autonomy expectations. International Association for Cross-Cultural Psychology. Sage Publication, DOI: 10.1177/00220221 09335185.

Kassim, A. W. (2006). Juveniles on remand: Trends and practices in Malaysia. United Nations Asia and Far East Institute Resource Material Series, 68, 196-208.

Kim, T., \& Goto, S. G. (2000). Peer delinquency and parental social support as predictors of Asian American adolescent delinquency. 
Deviant Behavior, 21, 331-347.

Klein, K., Forehand, R., Armistead, L., \& Long, P. (1997). Delinquency during the transition to early adulthood: family and parenting predictors from early adolescence. Adolescence, 32, 61-80.

Kumpfer, K. L. and Turner, C. W. (1991). The social ecology model of adolescent substance abuse: implications for prevention. The International Journal of the Addictions, 25(4A), 435-563.

Lai, S. C. (2011). Differences in parental marital quality and family environment between delinquent and non-delinquent adolescents. European Journal of Social Sciences, Vol, 24, No. 2.

Lee, L. K., Chen, C. Y., Lee, K. K., \& Kaur, J. (2007). Violence-related behavior among Malaysian adolescents: A cross-sectional survey among secondary school students in Negeri Sembilan. Annals of the Academy of Medicine, Singapore, 36(3), 169-174.

Loeber, R., \& Dishion, T. (1983). Early predictors of male delinquency: a review. Psychological Bulletin,94, 68-99.

Lorion, R. P., Bussell, D. and Goldberg, R. (1991).Identification of youth at high risk for alcohol or other drug problems. InGoplerud, E. N. (ed.), Preventing Adolescent Drug Use: From Theory to Practice. Office for Substance Abuse PreventionMonograph 8, USDHHS, PHS, ADAMHA, Rockville, MD, pp. 53-89.

Mai, N. T. (2009). The hidden addiction: Problem gambling amongst southeast Asian-American youth. Ph.D thesis, The California School of Professional Psychology, San Francisco Campus, Alliant International University, ProQuest Publication.

Malaysia Department of Social Welfare. (2006). Juvenile cases by state: 2000-2005. Retrieved 12 February 2013, from http://www. kpwkm.gov.my/BM/Upload/ Jadual9.13.pdf

Malaysia Ministry of Education. (2008). Kadlaporan: Pelanindukpembangunanpendidikan 2006-2010. Retrieved 12Febrauary 2013, from http://www.moe. gov.my/galeri_awam/selidik/2008/2008_BTMK_8_2023_7331.pdf

Malaysia Anti-Drug Association (PEMADAM).(2005). Data penagihterkumpul di Malaysia sejak 1998 sehingga 2005. Retrieved 12 February 2013, from http://www.pemadam.org.my/cda/m_fakta/fkt_sta_penagihan.php

Malaysia Department of Statistics.(2007). Population by age group and sex.Retrieved 12 February 2013, from http://www.kpwkm. gov.my/BM/Upload/20080624_034725_12064_j1.4.pdf

McBride, C. M., Curry, S. J, Cheadle, A., Anderman, C., Wagner, E. H., Diehr, P. and Psaty, B. (1995).School-level application of a social bonding model to adolescent risk taking behavior.Journal of School Health, 65(2), 63-68.

McCord, J. (1990).Problem behaviors. In Feldman, S. S. and Elliot, G. R. (eds), At the Threshold: The DevelopingAdolescent. Harvard University Press, Cambridge, pp. 431-456.

Mey, C. (2010). Psychological profile of adolescents in Malaysia.UniversitiSains Malaysia, Malaysia. The International Journal of Educational and Psychological Assessment, V(4).

Montessoro, A. C., \& Blixen, C. E. (1996). Public policy and adolescent pregnancy: A reexamination of the issues. Nursing Outlook, 44(1), 31-36.

Morton, S. G. B., Crump, D. A., Haynie, L. D and E. Saylor, E. K. (1999). Student-school bonding and adolescent problem behavior.HEALTH EDUCATION RESEARCH, Vol.14 no.1 1999, Theory \& Practice, Pages 99-107.

Naing, N. N., Ahmad, Z., Musa, R., Abdul Hamid, F. R., Ghazali, H., \& Abu Bakar, M. H. (2004). Factors related to smoking habits of male adolescents. Journal of Tobacco Induced Diseases, Vol. 2, No. 3: 133 -140.

Nyi Nyi Naing, Zulkifli Ahmad, Razlan Musa, Farique Rizal Abdul Hamid, Haslan Ghazali, Mohd Hilmi Abu Bakar. (2004). Factors Related to Smoking Habits of Male Adolescents. Tobacco Induced Diseases Vol. 2, No. 3: 133-140 (2004) @ PTID Society

Ozer, E. M., Macdonald, T. and Irwin, C. E. (2002). Adolescent health care in the United States: Implications and projections for the new millennium. In J. Mortimer and R. Larson (Eds.).The changing adolescent experience (pp. 129-174). New York: Cambridge University Press.

Pachauri, S., \& Santhya, K. G. (2002). Reproductive choices for Asian adolescents: A focus on contraceptive behavior. International Family Planning Perspectives, Vol. 28, No, 4.

Papathanasiou, I. and Lahana, E. (2007).Adolescence, sexuality and sexual education.ICUs Nursing Web Journal, 29-30, 1-8.

Pengpid, S., \& Peltzer, K. (2012). Alcohol use and associated factors among adolescent students in Thailand. West Indian Medical Journal.

Reinherz, H. Z., Paradis, A. D., Giaconia, R. M., Stashwick, C. K. and Fitzmaurice, G. (2003).Childhood and adolescent predictors of major depression in the transition to adulthood.American Psychiatry Journal, 160, 2141-2147.

Rotsztein, B. (1999). Risk-taking behavior and acculturation among adolescent refugees from Southeast Asia, Central America and their Quebec peers. A Master thesis, McGill University, Montreal, Canada.

Sanderson, C. A. (2000). The effectiveness of a sexuality education newsletter in influencing teenagers' knowledge and attitudes about sexual involvement and drug use. Journal of Adolescent Research, 15(6), 674-681.

Santrock, J. W. (2010). Adolescence.(13th ed.). New York: McGraw-Hill, Inc.

Santrock, J. W. (2011). Adolescence (13th ed.). New York: McGraw-Hill

Santrock, J. W. (2008). Adolescence (12th ed.). New York: McGraw-Hill.

Schinke, S. P., Botvin, G. J. and Orlandi, M. A. (1991).Substance Abuse in Children and Adolescents: Evaluationand Intervention. Sage, Newbury Park, CA.

Schmidt , J. A. (2003). Correlates of reduced misconduct among adolescents facing adversity. Journal of Youth and Adolescence Volume:32 Issue:6. Pages:439 to 452

Sidhu, A.S., The rise if crime in Malaysia: An academic and statistical analysis. Journal of the Kuala Lumpur Royal Malaysia Police College, 2005. 4: p. 1-28. 
Siegel, L. (1992). Criminology.Minn: West Pub Co.

Siti Nor, Y., Fui-Ping, W., Rozumah, B., Mariani, M., Rumaya, J., \& Mansor, A. T. (2010). Factors related to sexual knowledge among Malaysian adolescents. Jurnal Kemanusiaan bil 16, available at www.fppsm.utm.my/jurnal-kemanusiaan.html

Steinberg, L. (1990) Autonomy, conflicts, and harmony in the family relationship. In Feldman, S. S. and Elliot, G. R.(eds), At the Threshold: The Developing Adolescent. Harvard University Press, Cambridge, pp. 431-456.

Stewart, M. S., Bond, H. M,, Chang, M. C., Fielding, R., Deeds, O., \&Westrick, J. (1998). Parent and adolescent contributors to teenage misconduct in Western and Asian high school students in Hong Kong. International Journal of Behavioral Development, 22 (4), 847-869.

Soller, B., \& Lee, J. P. (2013). Drug-intake methods and social identity: The use of marijuana in blunts among southeast Asian adolescents and emerging adults. Journal of Adolescent Research.

Supple, A., Graves, K., Daniel, S., Kiang, L., Su, J., \& Cavanaugh, A.M. (2013). Ethnic, gender, and age differences in adolescent nonfatal suicidal behaviors. Death Studies. 37(9), 830-847.

Takanashi, R. (1993). The opportunities of adolescence.American Psychologist, 48, 85-87.

Ting, S. T. (2011). Antisocial behaviour among Malaysian adolescents. A Research project, Submitted in partial fulfillment of the requirements for the Bachelor of Social Science (Hons) Psychology, Faculty of Arts and Social Science, University Tunku Abdul Rahman, Malaysia.

USDHHS (1991) Healthy People 2000. National Health Promotion and Disease Prevention Objectives. USDHHS,PHS, Washington, DC.

Vu-Duc Vuong, K. M. S. S. (1991). AIDS knowledge, attitudes, beliefs and behaviors in Southeast Asian communities in San Francisco. The Online Archive of California, available at http://www.oac.collib.org/view?docld=hb3000053x\&query=\&brand=0ac4

Weisz, J. R., Chaiyasit, W., Weiss, B., Eastman, K. L., \& Jackson, E. W. (1995). A multimethod study of problem behavior among Thai and American children in school: Teacher reports versus direct observations. Child Development, 66, 402-415.

White, A. M. (2004). Brain development during adolescence.Retrieved 22 January 2008, from http://www.duke.edu/ amwhite/ Adolescence/adolescent3.html

WHO (2014). Tobacco. Available at http://www.who.int/mediacentre/factsheets/fs339/en/

WHO, (2012). Malaysia releases its first Global Adult Tobacco Survey. Culled from http://www.wpro.who.int/mediacentre/ releases/2012/20120613/en/

Xu, X., Fengchuan, R. N., Patricia, M. A., Victoria, M., \& Jacquelyn, C. (2005). Prevalence of and risk factors for intimate partner violence in China. American Journal of Public Health, 95(1), 78-85. http://dx.doi.org/10.2105/AJPH.2003.023978

Zhou, M. \& Bankston, C. (1998).Growing up American: How Vietnamese children adapt to life in the UnitedStates. New York: Russell Sage Foundation

Zulkefli, N. A. M., Abdul Rahman, H., Subramaniam, K., \& Teik Hua, L. (2005). Prevalence of motorcycle injuries among school students in Selangor, Malaysia. Proceedings of the Eastern Asia Society for Transportation Studies, Vol. 5, pp. 1857 -1866. 